\section{A) Check for updates}

Cite this: Mater. Adv., 2021, 2, 2636

Received 2nd December 2020, Accepted 2nd March 2021

DOI: 10.1039/d0ma00926a

rsc.li/materials-advances

\title{
Li-air battery and ORR activity of nanocarbons produced with good synthesis rate by solution plasma process $\dagger$
}

\author{
Md. Zahidul Islam, (D) anyarat Watthanaphanit, ${ }^{\mathrm{b}}$ Sangwoo Chae $\mathbb{D}^{\mathrm{a}}$ and \\ Nagahiro Saito (D) *acde
}

\begin{abstract}
Nanocarbons were successfully synthesized from benzene (BZ), nitro-benzene (BZ-NO 2$)$ and aniline $\left(B Z-\mathrm{NH}_{2}\right)$ by solution plasma process (SPP). The SPP was generated by a bipolar pulsed power supply between two tungsten electrodes at room temperature. The synthesized nanocarbons were investigated. The highest synthesis rate, $40 \mathrm{mg} \mathrm{min}^{-1}$, was for the BZ nanocarbon. The transmission electron microscopy (TEM) morphology showed that the nanocarbon sizes were $15-25 \mathrm{~nm}$. The Brunauer-Emmett-Teller (BET) analysis shows a highest surface area of $220 \mathrm{~m}^{2} \mathrm{~g}^{-1}$, pore size of $0.45 \mathrm{~cm}^{3} \mathrm{~g}^{-1}$, and average pore diameter of $20.0 \mathrm{~nm}$ for the BZ nanocarbon. Cyclic voltammetry (CV) in an acidic medium exhibited the oxygen reduction reaction (ORR) of the nanocarbons. The nanocarbon from $\mathrm{BZ}-\mathrm{NH}_{2}$ obtained a high special capacity of $15500 \mathrm{~mA} \mathrm{~h}$ per $\mathrm{g}$ of carbon at the discharge rate of $0.1 \mathrm{~mA} \mathrm{~cm}{ }^{-2}$ with $1.0 \mathrm{mg}$ carbon loading for the lithium (Li)-air battery. The ORR is an important reaction in Li-air batteries and fuel cells for the application of next-generation batteries and energy conversion devices.
\end{abstract}

\section{Introduction}

Recently, Li-air batteries have been used in energy conversion and storage devices for various applications. ${ }^{1-4}$ These face critical challenges that result from poor cycle life, low practical energy density, low round-trip efficiency, and high manufacturing costs. To improve the energy storage properties, catalytic activity and reduce the cost, ORR is demanded. ${ }^{5-7}$

Presently, platinum (Pt) is commonly used as a catalyst for ORR but it has high cost in the production and long term instability. ${ }^{8-10}$ To introduce alternatives to Pt catalysts, nanocarbons and heteroatom-doped nanocarbon have attracted attention. The advantages of nanocarbons and heteroatom-doped nanocarbon are the low production cost, excellent chemical properties and higher electrical conductivity. ${ }^{11,12}$

\footnotetext{
${ }^{a}$ Department of Chemical Systems Engineering, Graduate School of Engineering, Nagoya University, Nagoya 464-8603, Japan. E-mail: hiro@sp.material.nagoya-u.ac.jp

${ }^{b}$ Department of Chemistry, Faculty of Science, Mahidol University, 272 Thanon Rama VI, Thung Phaya Thai, Ratchathewi, Bangkok 10400, Thailand

${ }^{c}$ Japan Research for Evolutional Science and Technology (CREST), Japan Science and Technology Agency (JST), Kawaguchi, Saitama 332-0012, Japan

${ }^{d}$ Institutes for Innovation for Future Society, Nagoya University, Nagoya 464-8603, Japan

${ }^{e}$ Conjoint Research Laboratory in Nagoya University, Shinshu University, Furo-cho,

Chikusa, Nagoya 464-8603, Japan

† Electronic supplementary information (ESI) available. See DOI: 10.1039/ d0ma00926a
}

Nanocarbons such as carbon black, carbon nanotubes, porous and nonporous carbon materials and graphene have shown large specific surface areas, high conductivity, electrocatalytic activity, mechanical capacity, ultra-light characteristics, and chemical and thermal resistance. ${ }^{13-18}$ Heteroatom (nitrogen, boron, and phosphorus) doped nanocarbon has shown the higher ORR activity. ${ }^{19-23}$

Previously, the nanocarbon materials have been successfully synthesized by catalytic or noncatalytic chemical vapor deposition, pyrolysis, electric arc discharge, and direct-current (DC) discharge plasma from various organic solvents. ${ }^{24-29}$ However, these synthesis techniques are complicated due to their high process temperatures, low production yield, and the processing time. $^{30-33}$

Recently an energy saving and non-equilibrium liquid phase plasma named solution plasma process (SPP) has been used to synthesize nanocarbon materials at room temperature. ${ }^{34-38}$ In our laboratory, we conducted various experiments to produce carbon materials from organic solvents by SPP. ${ }^{39-42}$

In this research, nanocarbons were synthesised by SPP with different frequencies and pulse widths at an electrode distance of $0.75 \mathrm{~mm}$ for $30 \mathrm{~min}$. The synthesis rate is the main target in the synthesis of the nanocarbons along with their electrocatalytic activity (such as in Li-air batteries and fuel cells) without thermal treatment compared to the commercial Pt/C catalyst. The catalytic activity for ORR was obtained in acidic medium. The crystallinity, structure, surface area, morphology, elemental composition, 
electrical conductivity, ORR activity and Li-air battery performance of the nanocarbons were investigated. In the case of the Li-air battery, the $\mathrm{N}$-containing nanocarbon (nanocarbon of BZ- $\mathrm{NH}_{2}$ ) obtained a high special capacity of $15500 \mathrm{~mA} \mathrm{~h}$ per $\mathrm{g}$ of carbon compared with the nanocarbon of palm oils.

\section{Experimental procedure}

\subsection{Materials}

Benzene (>99\%; Kanto Chemical Co., INC., Japan), nitrobenzene (>99\%; Kanto Chemical Co., INC., Japan), aniline (>99\%; Kanto Chemical Co., INC., Japan), polyvinylidene fluoride (PVDF, SigmaAldrich, Japan), $N$-methyl-2-pyrrolidone (NMP, Kanto Chemical Co., INC., Japan), acetone (Kanto Chemical Co., INC., Japan) and ethanol (Kanto Chemical Co., INC., Japan) were purchased.

\subsection{Experimental setup and production procedure}

The experimental setup for SPP is shown in Fig. 1. The plasma was generated by a bipolar pulsed power supply (MPS-R06K01CWP1-6CH, Kurita Co. Ltd, Japan) between two tungsten (W) electrodes (wire type, purity 99.9\%, The Nilaco Corporation, Japan) with a $1 \mathrm{~mm}$ diameter, covered with an insulating ceramic tube. The electrode gap was $0.75 \mathrm{~mm}$ in the beginning. The concentra-

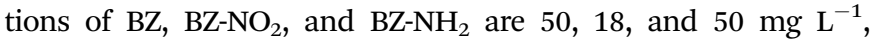
respectively. The applied high voltage had different pulse widths $(0.5,1.0$ and $2 \mu \mathrm{s})$ and repetition frequencies $(50,100$, and $150 \mathrm{kHz}$ ). The process time was $30 \mathrm{~min}$. The current and voltage waveforms were observed using an oscilloscope (DLM 2022, Yokogawa Meters \& Instruments Corporation, Japan) in the range of 0-5 A and 0.6-1.0 kV, respectively.

During SPP, the electrodes were adjusted several times, especially at high frequencies of SPP operation (i.e., 100 and $150 \mathrm{kHz}$ ) to keep a constant gap distance between the electrodes. Due to

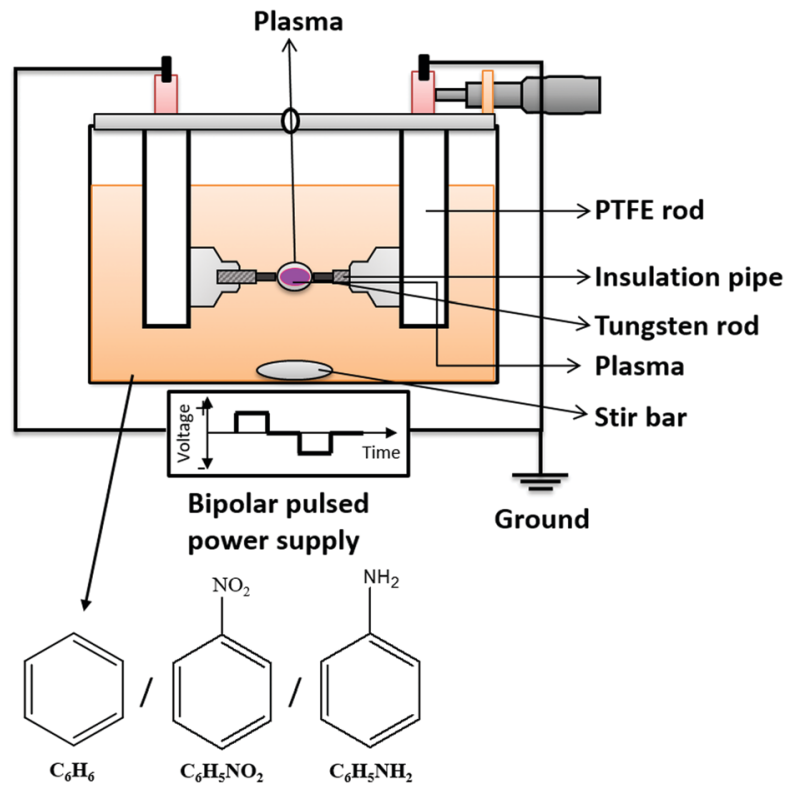

Fig. 1 Schematic diagram of experimental setup with precursors $\mathrm{BZ}$, $\mathrm{BZ}-\mathrm{NO}_{2}$ and $\mathrm{BZ}-\mathrm{NH}_{2}$ for solution plasma process (SPP). erosion, the electrode gap distance increases. This adjustment also has the role in maintaining a stable plasma during the process. If the electrode gap distance increases from $0.75 \mathrm{~mm}$ to $1 \mathrm{~mm}$ or more, the discharge stops. After the nanocarbon materials synthesis, the remaining liquid and solid phases were separated by filtration then dried at $90{ }^{\circ} \mathrm{C}$ for five hours in an oven (DX301, Yamato Co. Ltd, Japan). The weight of nanocarbon was measured using a balance (EK2000i, AS-ONE Co. Ltd, Japan). The carbon yield ( $Y$ in \%) and synthesis rate $\left(R\right.$ in $\mathrm{mg} \mathrm{min}^{-1}$ ) were calculated from the amount of carbon powders as:

$$
Y=\left(M / M_{0}\right) \times 100
$$

where $M$ is the mass of the carbon powder, and $M_{0}$ is the initial mass of BZ, BZ-NO $\mathrm{N}_{2}$ and $\mathrm{BZ}-\mathrm{NH}_{2}$. However, the synthesis rate was calculated as $R=M / T$. Where $T$ is total process time (i.e., $30 \mathrm{~min}$ ).

\subsection{Characterization}

The structural properties were investigated by X-ray diffraction (XRD, Rigaku Smart lab, Rigaku Corporation, Japan) with a Cu $\mathrm{K} \alpha \mathrm{X}$-ray radiation source at $\lambda=0.154 \mathrm{~nm}$ in the $2 \theta$ range from 3.0 to 90.0 degrees and a scan speed of 3.0 degrees; and Raman spectroscopy (NRS-100, JASCO Corporation, Japan) used a laser with a wavelength of $532.5 \mathrm{~nm}$ and $1 \mathrm{~mW}$ power to determine the types of nanocarbons. The morphology, shape, and size of the nanocarbons were observed using transmission electron microscopy (TEM, JEM-2500SE, JEOL Ltd, Japan) with an electron gun at $200 \mathrm{kV}$. The surface area, pore volume, and average pore diameter were observed using the Brunauer-EmmettTeller (BET, BELSORP-mini-II, BEL JAPAN, INC., Japan) method from the nitrogen adsorption-desorption isotherms at $77 \mathrm{~K}$. The elemental compositions were observed by X-ray photoelectron spectroscopy (XPS, PHI 5000 Versa Probe II; Ulvac-Phi physical Electronics INC., Japan) using a $\mathrm{Mg} \mathrm{K} \alpha \mathrm{X}$-ray source with a photon energy of $1253.6 \mathrm{eV}$. The electrical resistivity and electrical conductivity were determined using a four-point probe method (Laresta-GP, MCP-T610, Mitsubishi Chemical Analytech Co., Ltd, Japan). A concentration of $60 \mathrm{wt} \%$ of nanocarbons was mixed with $40 \mathrm{wt} \%$ polymer binder (PVDF) and then sonicated in NMP for $30 \mathrm{~min}$. The emulsion was dropped on a glass substrate, then dried in an electric oven at $120{ }^{\circ} \mathrm{C}$ for $20 \mathrm{~min}$ to form a uniform film.

\subsection{Electrochemical measurements}

Cyclic voltammetry (CV) measurements were conducted using a computer-controlled ALS-CH model 704 ES electrochemical analyzer ( $\mathrm{CH}$ Instrument Inc.). The ink made by ultrasonication of the catalyst $(5.0 \mathrm{mg})$, ultrapure water $(480 \mathrm{~mL})$, ethanol $(480 \mathrm{~mL})$, and Nafion ${ }^{\circledR}$ aqueous solution $(40 \mathrm{~mL}$ ) was obtained. The $\mathrm{Ag} / \mathrm{AgCl}$ solution was applied as the counter and reference electrodes with $0.5 \mathrm{~mol} \mathrm{~L}^{-1} \mathrm{H}_{2} \mathrm{SO}_{4}$ electrolyte under $\mathrm{N}_{2}$ and $\mathrm{O}_{2}$ gas saturation. The scan rate is $20 \mathrm{mV} \mathrm{s}^{-1}$ at $-0.2 \mathrm{~V}$ to $1.2 \mathrm{~V}(\mathrm{~V} v s$. $\mathrm{Ag} / \mathrm{AgCl})$.

\subsection{Fabrication of Li-air battery}

A Li-air battery was fabricated as shown in Fig. 2. The air electrode was fabricated by a mixture of nanocarbon and polyvinylidene difluoride (PVDF) as binder in a weight ratio of 70:30 at $8 \mathrm{MPa}$. 


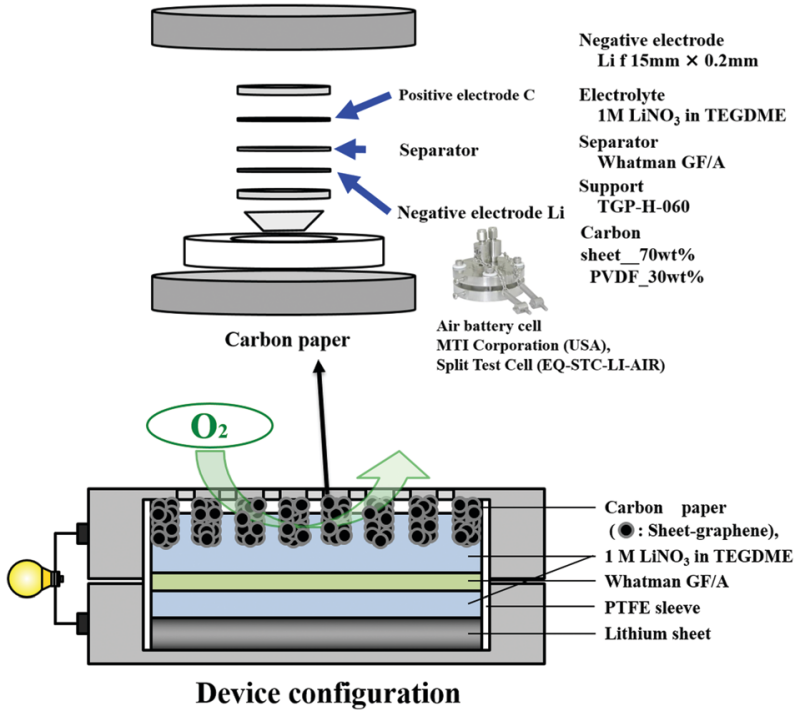

Fig. 2 Image of the Li-air battery fabricated from nanocarbon.

Lithium foil (thickness: $1 \mathrm{~mm}$ ) was purchased (Honjo Chemical Corp., Japan). Air battery cells (MTI Corporation, USA) and the electrode of $1 \mathrm{M} \mathrm{LiNO}_{3}$ in tetraethylene glycol dimethyl ether (TEGDME) were used. Battery tests were conducted with a Solar Tron SI $1280 \mathrm{~B}$ at current density of $0.1 \mathrm{~mA} \mathrm{~cm}{ }^{-2}$ for discharge and $0.5 \mathrm{~mA} \mathrm{~cm}{ }^{-2}$ for charge. The cut-off voltage in the discharge was set to $2.0 \mathrm{~V}$.

\section{Results and discussion}

\subsection{Synthesis rate}

Nanocarbons were synthesized from $\mathrm{BZ}, \mathrm{BZ}-\mathrm{NO}_{2}$ and $\mathrm{BZ}-\mathrm{NH}_{2}$ using SPP. After SPP, the synthesized nanocarbons were separated from the liquid, dried and the synthesis rates calculated (Fig. 3). The highest carbon yields $(Y)$ for $\mathrm{BZ}, \mathrm{BZ}-\mathrm{NO}_{2}$ and $\mathrm{BZ}-\mathrm{NH}_{2}$ are $1.92,0.32$ and $0.48 \%$, respectively, at $150 \mathrm{kHz}$ (see Table S1, ESI $\dagger$ ). The nanocarbons were showed the lowest synthesis rates

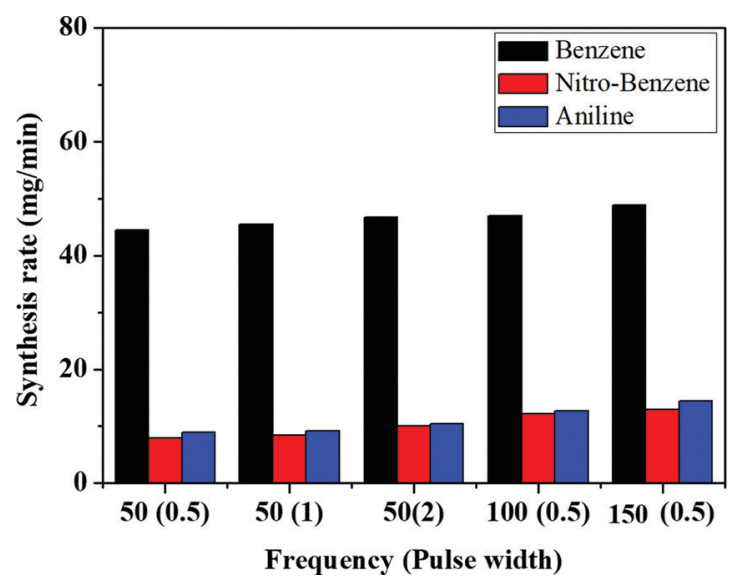

Fig. 3 Graph of the synthesis rate vs. frequency (pulse width) of the synthesized nanocarbons.
(42, 6 and $7 \mathrm{mg} \mathrm{min}^{-1}$ ) at $50 \mathrm{kHz}, 0.5 \mu \mathrm{s}$, and highest synthesis rates $\left(50,13\right.$ and $15 \mathrm{mg} \mathrm{min}^{-1}$ ) at $150 \mathrm{kHz}, 0.5 \mu \mathrm{s}$, for BZ, BZ-NO and $\mathrm{BZ}-\mathrm{NH}_{2}$ respectively. It confirms that when the frequencies were gradually increased, the synthesis rate also increased with them. ${ }^{43}$ In the case of $\mathrm{BZ}$, the synthesis rate of the nanocarbon was higher than for $\mathrm{BZ}-\mathrm{NO}_{2}$ and $\mathrm{BZ}-\mathrm{NH}_{2}$ due to their structures. It means that only the $\pi$-conjugated bond is successfully enhanced in the nanocarbon synthesis by SPP. The schematic of nanocarbon formation from BZ using SPP is shown in Fig. S1 (ESI $\dagger$ ). In this study, the highest synthesis rates of the nanocarbons at $150 \mathrm{kHz}, 0.5 \mu \mathrm{s}$ are described for the future investigation. So far in the paper, we have selected for the discussion only the data corresponding to the frequency of $150 \mathrm{kHz}$ with a pulse width of $0.5 \mu \mathrm{s}$.

\subsection{Morphology and surface area}

The TEM images confirmed the morphology. The morphologies of the nanocarbons from BZ, BZ- $\mathrm{NO}_{2}$ and $\mathrm{BZ}-\mathrm{NH}_{2}$ by SPP are seen in Fig. 4(a)-(c). The average diameters were in the 15-25 nm range with carbon in a ball-like shape. ${ }^{44}$ The nanocarbons were agglomerated with a few on the surface. The high-resolution TEM (HRTEM) images are shown in Fig. $4\left(\mathrm{a}^{\prime}\right)-\left(\mathrm{c}^{\prime}\right)$. Graphite-like structures with a good nanocarbon crystallinity were observed in the corresponding SAED images in Fig. $4\left(\mathrm{a}^{\prime \prime}\right)-\left(\mathrm{c}^{\prime \prime}\right)$. The SAED images show the (002), (100), and (101) planes of the nanocarbon. These data are confirmed in the XRD patterns.

The nanocarbon characteristics such as surface area, pore size, and diameter were determined using the Brunauer-EmmettTeller (BET) method (Table S2, ESI $\dagger$ ). For the BZ, BZ- $\mathrm{NH}_{2}$ and $\mathrm{BZ}-\mathrm{NO}_{2}$ nanocarbons, the BET surface areas were 220,230 and
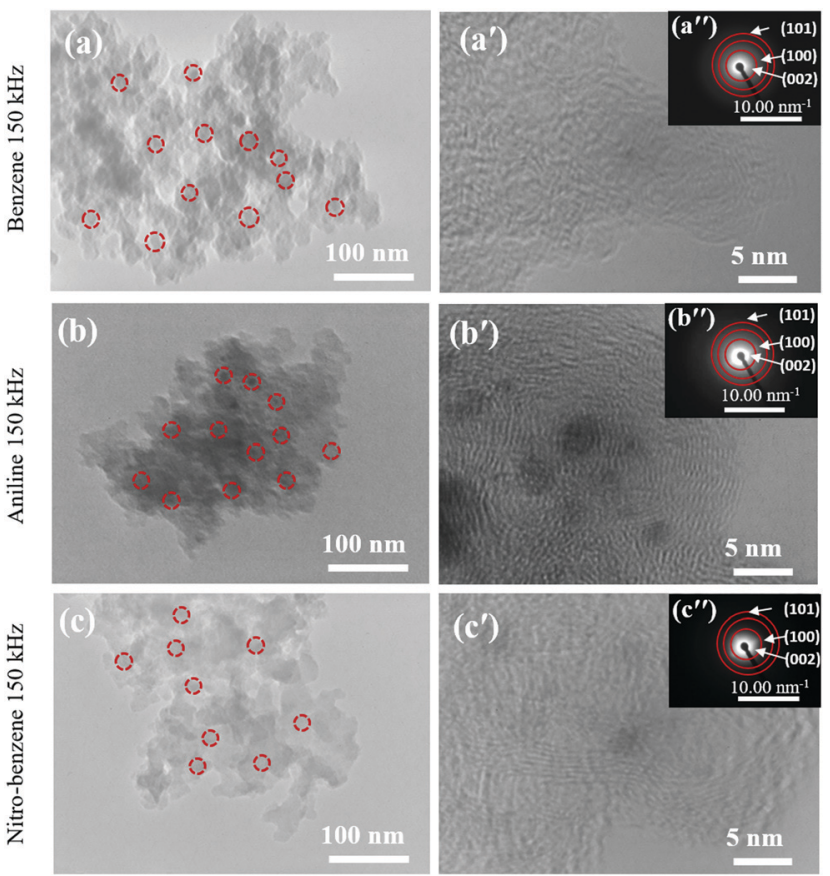

Fig. 4 (a-c) TEM images of the nanocarbons; $\left(a^{\prime}-c^{\prime}\right)$ HRTEM images; and $\left(a^{\prime \prime}-c^{\prime \prime}\right)$ SAED patterns (inset) for $\mathrm{BZ}, \mathrm{BZ}-\mathrm{NH}_{2}$ and $\mathrm{BZ}-\mathrm{NO}_{2}$ at $150 \mathrm{kHz}$ and $0.5 \mu \mathrm{s}$. 
$222 \mathrm{~m}^{2} \mathrm{~g}^{-1}$, the pore volumes were $0.45,0.49$ and $0.46 \mathrm{~cm}^{3} \mathrm{~g}^{-1}$, and the average pore diameters were 20.0, 17.0 and $15.0 \mathrm{~nm}$, respectively. The nanocarbon from $\mathrm{BZ}-\mathrm{NH}_{2}$ had an enhanced surface area of $230 \mathrm{~m}^{2} \mathrm{~g}^{-1}$.

\subsection{Structural properties}

The measured XRD patterns and Raman spectra are shown in Fig. 5. The XRD patterns of the $\mathrm{BZ}, \mathrm{BZ}-\mathrm{NH}_{2}$ and $\mathrm{BZ}-\mathrm{NO}_{2}$ nanocarbons (Fig. 5(a)) show a large peak at $23^{\circ}$ and a small broad peak at $44^{\circ}$ which correspond to the (002) and (100)/(101) planes, respectively, of the nanocarbon. ${ }^{45,46}$ The small and broad carbon shapes suggested that the graphite plane (JCPDS 75-1621) had quite good crystallinity. The sharp peaks of tungsten carbide (WC) (JCPDS \#25-1047) are observed in all the samples at $36^{\circ}, 42^{\circ}, 62^{\circ}$ and $74^{\circ}$ corresponding to the (111), (200), (220), (311) and (222) planes respectively. ${ }^{47}$ In the case of the $\mathrm{BZ}-\mathrm{NH}_{2}$ and $\mathrm{BZ}-\mathrm{NO}_{2}$ nanocarbons, the $\mathrm{WC}$ peaks were increased due to a higher sputtering of the tungsten electrode and the chemical structures compared with the nanocarbon from BZ. The chemical structures of $\mathrm{BZ}(\mathrm{C}-\mathrm{C}, \mathrm{C}=\mathrm{C}$ and $\mathrm{C}-\mathrm{H})$, $\mathrm{BZ}-\mathrm{NO}_{2}(\mathrm{C}-\mathrm{C}, \mathrm{C}=\mathrm{C}, \mathrm{C}-\mathrm{N}, \mathrm{N}=\mathrm{O}$ and $\mathrm{C}-\mathrm{H})$ and $\mathrm{BZ}-\mathrm{NH}_{2}(\mathrm{C}-\mathrm{C}$, $\mathrm{C}=\mathrm{C}, \mathrm{C}-\mathrm{N}, \mathrm{N}-\mathrm{H}$ and $\mathrm{C}-\mathrm{H}$ ) are different. The sputtering rate
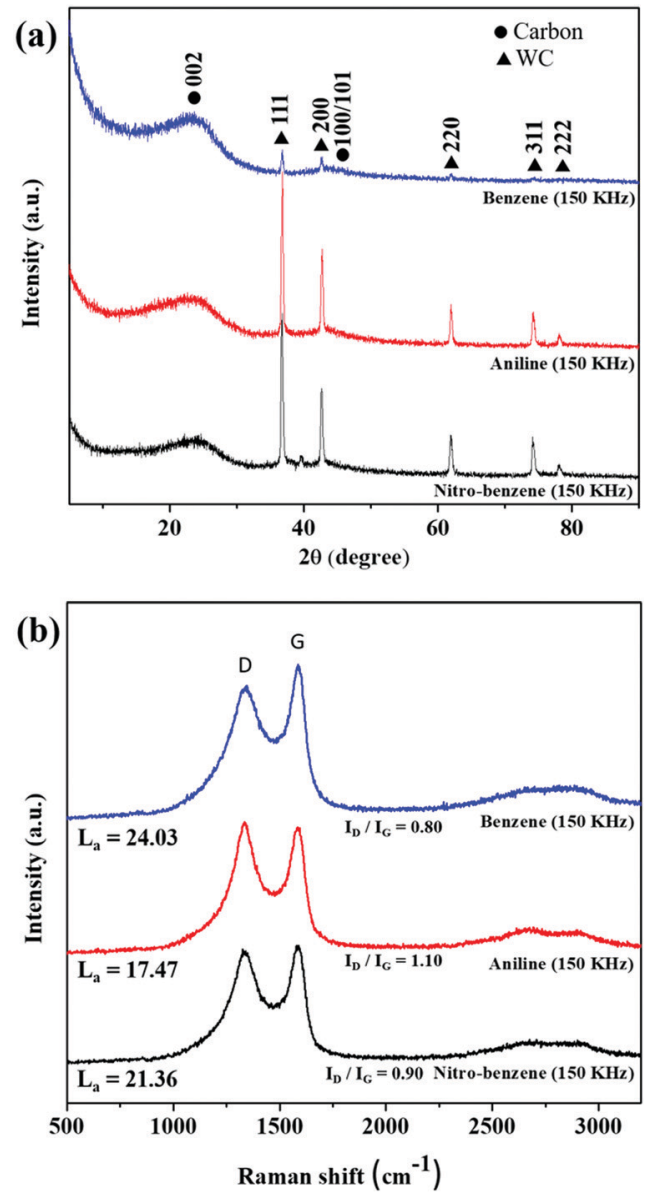

Fig. 5 The structural properties of the nanocarbons. (a) XRD patterns, and (b) Raman spectra for the nanocarbons from BZ, BZ-NH $\mathrm{H}_{2}$ and $\mathrm{BZ}-\mathrm{NO}_{2}$ at $150 \mathrm{kHz}$ and $0.5 \mu \mathrm{s}$. depends on the chemical structure of the solvents even under the same plasma conditions. During the solution plasma process, the solution conversion pathway has an effect on the results.

Fig. 5(b) shows that the $D\left(1350 \mathrm{~cm}^{-1}\right)$ and $\mathrm{G}\left(1600 \mathrm{~cm}^{-1}\right)$ band Raman peaks were observed in all samples. The D-band showed the structural disorders and defects, ${ }^{48}$ and the $\mathrm{G}$ band referred to $\mathrm{sp}^{2}$ graphite sheet-like structure nanocarbon. The $I_{\mathrm{D}} / I_{\mathrm{G}}$ ratios of $(0.80,1.10$ and 0.9$)$ for the $\mathrm{BZ}, \mathrm{BZ}-\mathrm{NH}_{2}$ and $\mathrm{BZ}-\mathrm{NO}_{2}$ nanocarbons were respectively calculated from the peaks. The $I_{\mathrm{D}} / I_{\mathrm{G}}$ values indicated the defect sites with degree of graphitization for the nanocarbons. ${ }^{49}$

The $I_{\mathrm{G}} / I_{\mathrm{D}}$ ratio is related to the crystallite size $L_{\mathrm{a}}$ using the Tuinstra-Koenig relationship as follows: ${ }^{50}$

$$
L_{\mathrm{a}}(\mathrm{nm})=\left(2.4 \times 10^{-10}\right) \lambda^{4}\left(I_{\mathrm{G}} / I_{\mathrm{D}}\right),
$$

where $\lambda$ is the Raman excitation wavelength at $532 \mathrm{~nm}$. The $L_{\mathrm{a}}$ values are correlated to the inter-defect distance of the surface. The $L_{\mathrm{a}}$ value of the $\mathrm{BZ}-\mathrm{NH}_{2}$ nanocarbon showed the $\mathrm{BZ}-\mathrm{NH}_{2}$ nanocarbon to have more defect sites due to its nitrogen molecules.

The XRD and Raman results corresponded with the TEM images and showed that the nanocarbons were graphite-like structures with crystallinity.

\subsection{Electrical conductivity and composition}

The four-point probe method was applied to the nanocarbons to identify resistance $(\Omega)$, surface resistance $\left(\Omega \mathrm{cm}^{-2}\right)$, resistivity $\left(\Omega \mathrm{cm}^{-1}\right)$ and electrical conductivity $\left(\mathrm{S} \mathrm{cm}^{-1}\right)$ (see Tables S3-S5, ESI, $\dagger$ and Fig. 6). So, we observed that when the resistivity $\left(\Omega \mathrm{cm}^{-1}\right)$ of the nanocarbon was decreased, the conductivity was increased. In the case of the BZ nanocarbon, it shows the highest electrical conductivity compared with the nanocarbons from $\mathrm{BZ}-\mathrm{NH}_{2}$ and $\mathrm{BZ}-\mathrm{NO}_{2}$. The elemental composition was found using XPS spectroscopy, as shown in Fig. S2 (ESI $\dagger$ ). The BZ nanocarbon (C1s 99.6, and W4f 0.4 atom\%), BZ- $\mathrm{NH}_{2}$ nanocarbon (C1s 98.2, N1s 1.6, and W4f 0.2 atom\%), and $\mathrm{BZ}-\mathrm{NO}_{2}$ nanocarbon (C1s 97.1, O1s 15.9, N1s 5.0 and $\mathrm{W}<0.1$, atom\%) were identified at $150 \mathrm{kHz}$ and $0.5 \mu \mathrm{s}$. The XPS spectroscopy

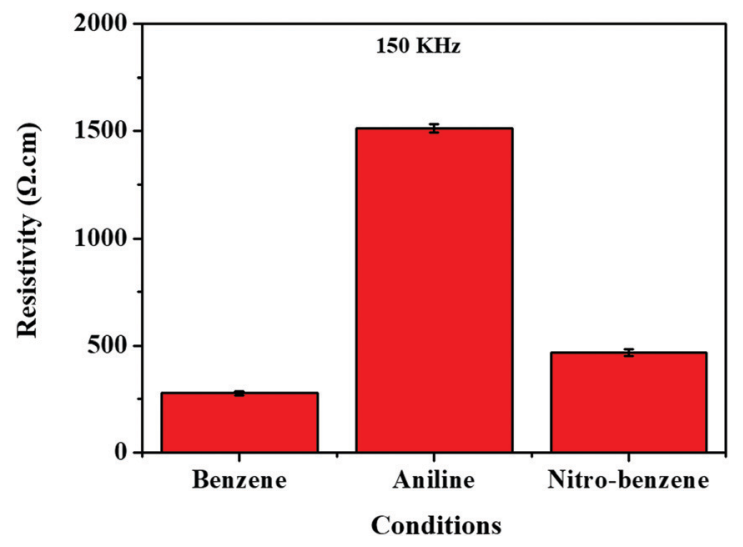

Fig. 6 Electrical resistivity using the four probe method for the nanocarbons under various conditions. 
data showed that BZ nanocarbon contained carbon (C) and tungsten (W); BZ- $\mathrm{NH}_{2}$ nanocarbon contained carbon (C), nitrogen $(\mathrm{N})$ and tungsten $(\mathrm{W})$; and $\mathrm{BZ}-\mathrm{NO}_{2}$ nanocarbon contained carbon $(\mathrm{C})$, oxygen $(\mathrm{O})$, nitrogen $(\mathrm{N})$ and tungsten $(\mathrm{W})$, corresponding with the XRD patterns.

\subsection{Catalytic activity}

The ORR electrocatalytic activity was also tested in $0.5 \mathrm{~mol} \mathrm{~L}^{-1}$ $\mathrm{H}_{2} \mathrm{SO}_{4}$ solution with $\mathrm{N}_{2}$ and $\mathrm{O}_{2}$ saturation at $20 \mathrm{mV} \mathrm{s}{ }^{-1}$ scan rate, as shown in Fig. 7(a)-(c). The anodic and cathodic peaks are shown in the potential range of -0.2 to $1.2 \mathrm{~V}$. Under $\mathrm{N}_{2}$-saturation featureless $\mathrm{CV}$ curves can be observed for the $\mathrm{BZ}$ and $\mathrm{BZ}-\mathrm{NO}_{2}$ nanocarbons as shown in Fig. 7(a) and (b). On the other hand, the $\mathrm{CV}$ curve with $\mathrm{O}_{2}$-saturated electrolyte shows a cathodic peak around $0.4 \mathrm{~V}$ corresponding to ORR. The ORR catalytic activity has use in fuel-cell applications as a cathode. Fig. 7d presents the LSV curves of $\mathrm{BZ}, \mathrm{BZ}-\mathrm{NO}_{2}$ and BZ- $\mathrm{NH}_{2}$ in $\mathrm{O}_{2}$-saturated $0.5 \mathrm{~mol} \mathrm{~L}^{-1} \mathrm{H}_{2} \mathrm{SO}_{4}$ solution at a scan rate of $10 \mathrm{mV} \mathrm{s}^{-1}$ with a rotation speed of $1600 \mathrm{rpm}$. The LSV curve was obtained with an onset potential of $0.39 \mathrm{~V}$ for $\mathrm{BZ}-\mathrm{NH}_{2}$. Moreover, the current density of $\mathrm{BZ}-\mathrm{NH}_{2}$ was larger than for $\mathrm{BZ}$ and $\mathrm{BZ}-\mathrm{NO}_{2}$ and was investigated. The $\mathrm{BZ}-\mathrm{NH}_{2}$ nanocarbon showed a synergistic effect of $\mathrm{N}$ and $\mathrm{WC}$ on the ORR activity. The specific capacity shows such a difference to various nanocarbons due to the properties of the tungsten (W), nitrogen $(\mathrm{N})$ and oxygen $(\mathrm{O})$ containing nanocarbons. In the case of $\mathrm{BZ}-\mathrm{NH}_{2}$, the synergistic effect of $\mathrm{N}$ and WC doping on the ORR activity was compared with $\mathrm{BZ}$ and $\mathrm{BZ}-\mathrm{NO}_{2} . \mathrm{BZ}-\mathrm{NH}_{2}$ showed enhanced carbon properties, such as surface area, resistivity, nitrogen configuration and degree of graphitization, which played a role in the improved ORR activity in the acid media compared with $\mathrm{BZ}$ and $\mathrm{BZ}-\mathrm{NO}_{2}$.
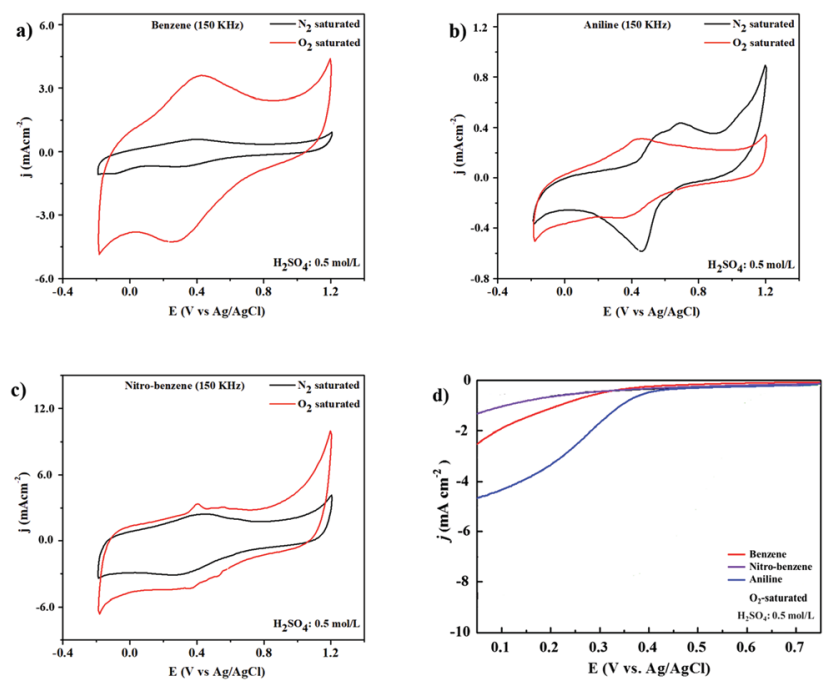

Fig. $7 \mathrm{CV}$ measurements of (a) benzene (BZ), (b) aniline $\left(\mathrm{BZ}-\mathrm{NH}_{2}\right)$ and (c) nitrobenzene $\left(B Z-\mathrm{NO}_{2}\right)$ in $0.5 \mathrm{~mol} \mathrm{~L}^{-1} \mathrm{H}_{2} \mathrm{SO}_{4}$ solution at a scan rate of $20 \mathrm{mV} \mathrm{s}^{-1}$ under $\mathrm{N}_{2}$ (black lines) and $\mathrm{O}_{2}$ (red lines) saturation. LSV measurements: (d) presents the LSV curves of $\mathrm{BZ}, \mathrm{BZ}-\mathrm{NH}_{2}$, and $\mathrm{BZ}-\mathrm{NO}_{2}$ in $\mathrm{O}_{2}$-saturated $0.5 \mathrm{~mol} \mathrm{~L}^{-1} \mathrm{H}_{2} \mathrm{SO}_{4}$ solution at a scan rate of $10 \mathrm{mV} \mathrm{s}^{-1}$ with a rotation speed of $1600 \mathrm{rpm}$.

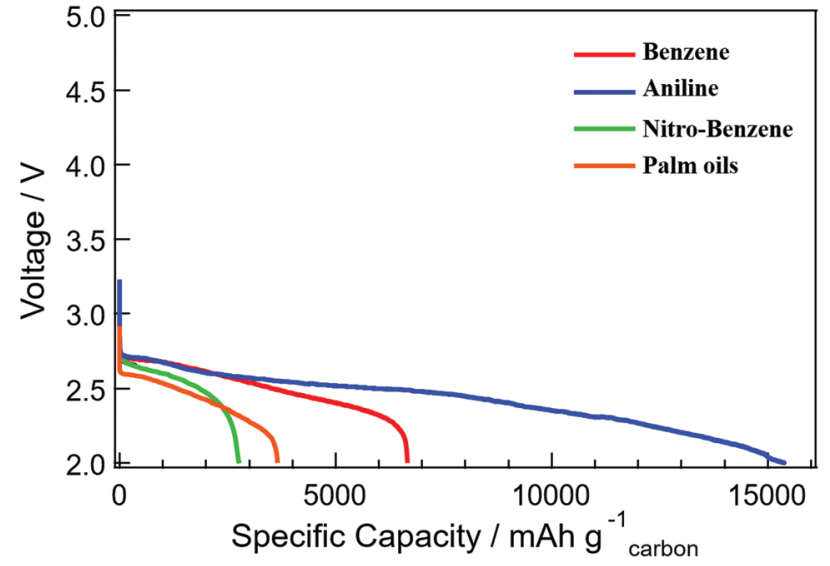

Fig. 8 The discharge curves of the Li-air batteries with $1.0 \mathrm{mg}$ carbon loadings at $0.1 \mathrm{~mA} \mathrm{~cm}{ }^{-2}$ rates for nanocarbons from $\mathrm{BZ}, \mathrm{BZ}-\mathrm{NH}_{2}, \mathrm{BZ}-\mathrm{NO}_{2}$ and palm oils.

\subsection{Li-air battery test}

The electrochemical performances of the cell voltage and capacity of the Li-air batteries, the discharge of $1.0 \mathrm{mg} \mathrm{cm} \mathrm{cm}^{-2}$ carbon loading in 1.0 atom of dry oxygen at $0.1 \mathrm{~mA} \mathrm{~cm} \mathrm{~cm}^{-2}$ rates, are shown in Fig. 8. The specific capacities of 2800, 3600, 6700 and $15000 \mathrm{~mA} \mathrm{~h}$ per $\mathrm{g}$ of carbon were identified for the nanocarbons from $\mathrm{BZ}-\mathrm{NO}_{2}$, palm oils, $\mathrm{BZ}$ and $\mathrm{BZ}-\mathrm{NH}_{2}$ respectively at the rate

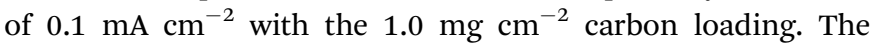
highest special capacity of $15500 \mathrm{~mA} \mathrm{~h}$ per $\mathrm{g}$ of carbon was obtained for the BZ- $\mathrm{NH}_{2}$ nanocarbon, compared with the palm oils nanocarbon.

\section{Conclusions}

We have synthesized the nanocarbons by solution plasma process. The highest synthesis rate was observed for the nanocarbon from BZ. The graphite-like structure and the 15-25 nm sized nanocarbons were investigated using the TEM images supported by XRD and Raman spectroscopy measurements. In the ORR electrocatalytic activity of the nanocarbons, the cathodic peak at $0.4 \mathrm{~V}$ was clearly observed for all samples. The performance of the Li-air battery, with the highest special capacity of $15500 \mathrm{~mA} \mathrm{~h}$ per $\mathrm{g}$ of carbon for the $\mathrm{BZ}-\mathrm{NH}_{2}$ nanocarbon, was compared with the nanocarbon of palm oils. We believe that SPP could be able to synthesise nanocarbons with electrocatalytic activity for applications such as $\mathrm{Li}$-air batteries and fuel cells.

\section{Conflicts of interest}

There are no conflicts to declare.

\section{Acknowledgements}

This research was financially supported by Core Research for Evolutional Science and Technology (CREST) of Japan Science and Technology Agency (JST). The grant number is JST/CREST Grant No. GJPMJCR12L1 . 


\section{Notes and references}

1 S. W. Lee, N. Yabuuchi, B. M. Gallant, S. Chen, B.-S. Kim, P. T. Hammond and Y. Shao-Horn, Nat. Nanotechnol., 2010, 5, 531. 2 A. Chen and P. Holt-Hindle, Chem. Rev., 2010, 110, 3767.

3 X. Ma, H. Meng, M. Cai and P. Shen, J. Am. Chem. Soc., 2012, 134, 1954.

4 Y. Zhao, L. Yang, S. Chen, X. Wang, Y. Ma, Q. Wu, Y. Jiang, W. Qian and Z. Hu, J. Am. Chem. Soc., 2013, 135, 1201.

5 B. Winther-Jensen, O. Winther-Jensen, M. Forsyth and D. R. MacFarlane, Science, 2008, 321, 671.

6 Y. Zheng, Y. Jiao, J. Chen, J. Liu, J. Liang, A. Du, W. Zhang, Z. Zhu, S. C. Smith, M. Jaroniec, G. Q. Lu and S. Z. Qiao, J. Am. Chem. Soc., 2011, 133, 20116.

7 Z. Schnepp, Y. Zhang, M. J. Hollamby, B. R. Pauw, M. Tanaka, Y. Matsushita and Y. Sakka, J. Mater. Chem. A, 2013, 1, 13576. 8 H. Wang, T. Maiyalagan and X. Wang, ACS Catal., 2012, 2, 781. 9 C. Soldano, A. Mahmood and E. Dujardin, Carbon, 2010, 48, 2127-2150.

10 A. Manikandan, L. Lee, Y.-C. Wang, C.-W. Chen, Y.-Z. Chen, H. Medina, J.-Y. Tseng, Z. M. Wang and Y.-L. Chueh, J. Mater. Chem. A, 2017, 5, 13320-13328.

11 Z. Yang, W. Sun, L. Wang, Z. Wan, J. Wang, S. Wang and G. Liu, Corros. Sci., 2020, 175, 108860.

12 M. Topsakal, H. Şahin and S. Ciraci, Phys. Rev. B: Condens. Matter Mater. Phys., 2012, 85, 155445.

13 J. Liang, Y. Jiao, M. Jaroniec and S. Z. Qiao, Angew. Chem., Int. Ed., 2012, 51, 11496-11500.

14 Q. Lv, W. Si, J. He, L. Sun, C. Zhang, N. Wang, Z. Yang, X. Li, X. Wang and W. Deng, Nat. Commun., 2018, 9, 1-11.

15 S. Chen, A. Zehri, Q. Wang, G. Yuan, X. Liu, N. Wang and J. Liu, ChemistryOpen, 2019, 8, 58-63.

16 W. Lei, H. M. Barnes, J. Zhang and Z. Cai, Wood Fiber Sci., 2017, 49, 22-32.

17 S. W. Lee, B. M. Gallant, H. R. Byon, P. T. Hammond and Y. Shao-Horn, Energy Environ. Sci., 2011, 4, 1972.

18 S. W. Lee, B.-S. Kim, S. Chen, Y. Shao-Horn and P. T. Hammond, J. Am. Chem. Soc., 2009, 131, 671.

19 A. Watthanaphanit, G. Panomsuwan and N. Saito, $R S C A d v$., 2014, 4, 1622.

20 G. Panomsuwan, A. Watthanaphanit, T. Ishizaki and N. Saito, Phys. Chem. Chem. Phys., 2015, 17, 13794.

21 T. Ishizaki, S. Chiba, Y. Kaneko and G. Panomsuwan, J. Mater. Chem. A, 2014, 2, 10589-10598.

22 T. Morishita, T. Ueno, G. Panomsuwan, J. Hieda, A. Yoshida, M. A. Bratescu and N. Saito, Sci. Rep., 2016, 6, 36880.

23 X. Hu, X. Shen, O. Takai and N. Saito, J. Alloys Compd., 2013, 552, 351-355.

24 S. Chae, G. Panomsuwan, M. A. Bratescu, K. Teshima and N. Saito, ACS Appl. Nano Mater., 2019, 2, 1350-1355.
25 C. Chokradjaroen, S. Kato, K. Fujiwara, H. Watanabe, T. Ishii and T. Ishizaki, Sustainable Energy Fuels, 2020, 4, 4570-4580.

26 O. L. Li, S. Chiba, Y. Wada, G. Panomsuwan and T. Ishizaki, J. Mater. Chem. A, 2017, 5, 2073-2082.

27 M. A. Bratescu, O. Takai and N. Saito, J. Alloys Compd., 2013, 562, 74-83.

28 K. Hyun, T. Ueno, O. L. Li and N. Saito, $R S C A d v .$, 2016, 6, 6990-6996.

29 C. H. Choi, S. H. Park and S. I. Woo, J. Mater. Chem., 2012, 22, 12107-12115.

30 G. Panomsuwan, N. Saito and T. Ishizaki, J. Mater. Chem. A, 2015, 3, 9972-9981.

31 N. Thongwichit, O. L. H. Li, W. Yaowarat, N. Saito and U. Suriyapraphadilok, Jpn. J. Appl. Phys., 2016, 55, 01AE10.

32 J. Kim, J. Chun, S.-G. Kim, H. Ahn and K. C. Roh, J. Electrochem. Sci. Technol., 2017, 8, 338-343.

33 D.-w. Kim, O. L. Li and N. Saito, Phys. Chem. Chem. Phys., 2014, 16, 14905-14911.

34 O. Takai, Pure Appl. Chem., 2008, 80, 2003-2011.

35 G. Panomsuwan, N. Saito and T. Ishizaki, Phys. Chem. Chem. Phys., 2015, 17, 6227.

36 W. Wang, S. Chakrabarti, Z. Chen, Z. Yan, M. O. Tade, J. Zou and Q. Li, J. Mater. Chem. A, 2014, 2, 2390-2396.

37 T. Sudare, T. Ueno, A. Watthanaphanit and N. Saito, Phys. Chem. Chem. Phys., 2015, 17, 30255-30259.

38 K. Hyun, T. Ueno, O. L. Li and N. Saito, RSC Adv., 2016, 6, 6990-6996.

39 T. Morishita, T. Ueno, G. Panomsuwan, J. Hieda, A. Yoshida, M. A. Bratescu and N. Saito, Sci. Rep., 2016, 6, 36880.

40 J. Kang, O. L. Li and N. Saito, Nanoscale, 2013, 5, 6874.

41 D. Kim, O. L. Li, P. Pootawang and N. Saito, RSC Adv., 2014, 4, 16813.

42 S. Lee, Y. Heo, M. A. Bratescu, T. Ueno and N. Saito, Phys. Chem. Chem. Phys., 2017, 19, 15264-15272.

43 O. L. Li, H. Hayashi, T. Ishizaki and N. Saito, RSC Adv., 2016, 6, 51864 .

44 D. Kim, O. L. Li and N. Saito, Phys. Chem. Chem. Phys., 2015, 17, 407.

45 G. Panomsuwan, S. Chiba, Y. Kaneko, N. Saito and T. Ishizaki, J. Mater. Chem. A, 2014, 2, 18677.

46 X. Zhang and Z. Lix, Nanoscale, 2012, 4, 707-714.

47 T. Murphy, R. Hayes, S. Imberti, G. G. Warr and R. Atkin, Phys. Chem. Chem. Phys., 2014, 16, 13182-13190.

48 K. F. Adekunle, Open J. Polym. Chem., 2015, 5, 34-40.

49 N. Taufiqurrahmi and S. Bhatia, Energy Environ. Sci., 2011, 4, 1087-1112.

50 L. G. Cançado, K. Takai, T. Enoki, M. Endo, Y. A. Kim, H. Mizusaki, A. Jorio, L. N. Coelho, R. M. Paniago and M. A. Pimenta, Appl. Phys. Lett., 2006, 88, 163106. 